\title{
Jorma Kalela
}

\section{Historia ja kertomus \\ Miten historiaa oikeastaan kannattaisi ajatella?}

Historia ei ole vain tiedon laji, vaan myös ihmiselämän erottamaton osa. Historioiden rakentaminen on ihmiselle yhtä välttämätöntä kuin syöminen tai hengittäminen, kuten yhdysvaltainen historiantutkija David Thelen (1988) on sattuvasti todennut. Valtaosa viittauksista jo tapahtuneeseen on satunnaisia toteamuksia, mutta myös tarkoituksella laadittuja menneen esityksiä syntyy koko ajan. Kertomus taas on näiden historioiden yleisin muoto; historiahan on monissa kielissä jutun tai kertomuksen synonyymi.

Englantilaisen historiantutkijan Raphael Samuelin $(1994,17)$ huomautus havainnollistaa asian: jos historia ajateltaisiin mennyttä tulkitsevaksi toiminnaksi eikä ammatiksi, sen harjoittajia olisi lukematon määrä. Historiantutkijoiden esitykset ovatkin vain yksi historioiden lajityyppi. Historioita rakennetaan kaikilla yhteiskunnan alueilla, ja niiden tuottajien joukko on epälukuinen alkaen yksityisistä ihmisistä ja ulottuen vaikkapa puolueisiin ja eri medioihin.

Jokaisella ihmisellä on oma ainutkertainen menneisyytensä, ja siksi menneisyys yksikössä on syytä ajatella teoreettiseksi käsitteeksi. Samalla tavalla, tekemällä ero konkreettisen ja teoreettisen asiayhteyden välille, on ajateltava myös historiaa ja historioita. Ihmisten omat historiat, ja kertomus niiden yhtenä muotona, toimivat hedelmällisinä lähtökohtina, kun ajatellaan minkä tahansa yhteisön tai yhteiskunnan historiaa.

Kirjallisuudentutkimuksen näkökulmasta ihmisten omat historiat ovat arkipuheen, eivät taiteen kertomuksia, vaikka ne voivat toimia myös kirjallisuuden lähtökohtana. Kun niitä lähestytään yksilökeskeisestä näkökulmasta, voidaan esimerkiksi analysoida tietyn henkilön tapaa rakentaa historiaa. Mutta näkökulma voi olla myös kollektiivinen, kuten folkloristisessa historiallisen tarinan erittelyssä, jota Outi Lehtipuro on esitellyt (1982). Samantyyppinen on Matti Hyvärisen hiljan (2012) suosittama sosiologinen, lingvistinen ja retorinen kerronnan tutkimus, jossa tarkastelun painopiste on siirretty yksittäisten kertomusten kokoamisesta ja analyysistä kohti etnografista otetta.

\section{"Kirjoitettu kansakunta"}

Yhteiskunnan ja kulttuurin tutkimuksessa tapahtui 1900-luvun viimeisellä neljänneksellä merkittävä muutos, kun käsitys kielestä tiedon välittämisen neutraalina välineenä todettiin kestämättömäksi. "Objektiivisen todellisuuden" tavoittelu kävi ongelmalliseksi, jos hyväksyi näkemyksen siitä, että todellisuuskäsityksiä ehdollistaa aina kieli, 
jolla ne joudutaan ilmaisemaan. Tämä kielelliseksi käänteeksi kutsuttu ilmiö muutti tutkimuksen kohteita tavalla, jota on havainnollistanut yhdysvaltalaisessa Cornellin yliopistossa työskentelevä politiikantutkija Benedict Anderson.

Andersonin vuonna 1983 ilmestynyt, nationalismia käsittelevä Imagined Communities avasi nopeasti maailmanlaajuisen keskustelun tästä teemasta. Hän korosti, että kansakuntaa on syytä lähestyä kuvitteellisena yhteisönä, joka on olemassa yhteisenä (shared), kyseenalaistamattomana mielikuvana. Andersonia (1983, takakansi) itseään kiinnosti, "mikä saa ihmiset elämään ja kuolemaan kansakunnan puolesta sekä vihaamaan ja tappamaan sen puolesta".

Tämän puheenvuoron näkökulmasta Andersonin tutkimus muistuttaa, ettei kansa ole mikään ylihistoriallinen ilmiö, jonka olemassaolo voidaan ottaa annettuna, kuten moni suomalainen historianprofessori teki vielä 1980-luvulla. Sen sijaan että kysyttäisiin, miten ja milloin aina olemassa olevaksi oletetun subjektin piirteet tuotiin esiin, on perustellumpaa kysyä, miten kansakunta rakennettiin.

Juuri ilmestynyt Kirjoitettu kansakunta. Sukupuoli, uskonto ja kansallinen historia 1900-luvun alkupuolen suomalaisessa tietokirjallisuudessa (2013) avaa "näkökulman yksiäänisyyden purkamiseen", kuten teoksen toimittajat Marja Jalava, Tiina Kinnunen ja Irma Sulkunen ilmaisevat tavoitteensa. Teoksessa eritellyt ristiriitaiset ja monikerroksiset prosessit osoittavat, että on todella syytä luopua "historiallisen yhtenäiskulttuurin ideaalista" ja kiinnittää huomio akateemisen historiantutkimuksen ulkopuolella tuotettuihin historian moninaisiin kirjallisiin esitysmuotoihin (Jalava et al. 2013, 8).

Tarkastelun kohteiksi valitut 1900-luvun alkupuolen kirjoittajat edustivat sivistyneistön eri ryhmiä koulunopettajista ja poliitikoista kirjailijoihin ja professoreihin. Kellään heistä ei ollut historia-alan yliopistollista koulutusta. Teoksessa tarkastellaan Juhani Ahoa, Maria Ramstedtia, Eliel Aspelin-Haapkylää, Maila Talviota, Ester Hällströmiä, Hilda Käkikoskea, Alexandra Gripenbergiä, Valfrid Vaseniusta, Paavo Virkkusta ja Tyyni Tuuliota. Kukin heistä rakensi tietoisesti kansakuntaa omalla tavallaan.

Kirjoitettu kansakunta dokumentoi tärkeän asennemuutoksen. Kuten sen toimittajat korostavat, "historian ammattilaiset ovat havahtuneet siihen tosiasiaan, ettei heidän tuotoksillaan ole suurtakaan merkitystä muiden ihmisten menneisyyttä koskevien käsitysten rakentumiselle" (Jalava et al. 2013, 7).

\section{Monien historioiden vaikutukset}

Toisen näkökulman historia-ammattilaisten vaikutuksen ylikorostamiseen dokumentoi Sirkka Ahonen viime vuonna ilmestyneellä tutkimuksellaan Coming to Terms with a Dark Past. How Post-Conflict Societies Deal with History. Suomi, Etelä-Afrikka ja Bosnia-Herzegovina ovat varsin erilaisia yhteiskuntia, ja siksi niiden tarkastelu samassa 
tutkimuksessa on historiantutkijalta paitsi rohkea myös hedelmällisiä tuloksia tuottanut päätös. Hämmentävintä Ahosen teoksessa on se samankaltaisuus, jolla noissa kolmessa maassa on tarkasteltu omaa sisällissotaa jälkeenpäin - niiden erilaisuudesta huolimatta. Erot eivät ole estäneet samojen myyttien soveltamista syyllisyyttä ja uhriutta koskevien esitysten muotteina.

Sirkka Ahonen on suomalaisen historiadidaktiikan grand old lady, ja juuri opettajankoulutus alleviivaa hänen tulostensa merkittävyyttä. Oman tehtävänsä vakavasti ottava opettaja joutuu työssään ottamaan kantaa oppilaittensa arkisessa ympäristössä vaikuttaviin käsityksiin ja uskomuksiin. Hän ei pysty kiertämään menneen esitysten erilaisia seurauksia, kuten monet tutkijat mielellään tekevät objektiivisuuden nimissä.

Ahosen tutkimuksen punaisena lankana ovat mahdollisuudet välttää vihollisuuksien jatkuminen historiantulkintojen tasolla. Ratkaisuna ei voi olla "ylhäältä tuleva" tulkintojen tyrkyttäminen, kuten Ahonen muistuttaa viittaamalla entisiin sosialistimaihin. Tulokset vaikeiden menneisyyksien sulkemisesta keskustelun ulkopuolelle ovat yhtä huonoja. Olisi päästävä monia näkökulmia sisältävään, yhteisön hyväksymään lähestymistapaan.

Kirjoitetun kansakunnan toimittajien tavoin Ahonen korostaa välttämättömyyttä luopua yhtenäisen kansallisen kertomuksen ideaalista, jossa lähdetään liikkeelle ajatteluja tulkintatyön lopputuloksesta. Omalta osaltani suositan viime vuonna ilmestyneessä Making History -teoksessa päinvastaista lähestymistapaa. Sen alkupisteenä on monien erilaisten historioiden vuorovaikutus, koskaan päättymätön historian yhteiskunnallisen rakentamisen prosessi.

\section{Historia dialogina}

Historioita rakennetaan, koska menneitä asioita ja tapahtumia pidetään merkityksellisinä nykyhetken kannalta. Menneen esitykset onkin perusteltua ajatella tuloksiksi väittelystä siitä, mistä huomion kohteena olevissa asioissa ylipäätään on kysymys. Debattia käyvät nykyisyyden ihmiset niiden ihmisten kanssa, joiden asioista he ovat kiinnostuneet. Historian mieli on juuri vuoropuhelussa sellaisten ihmisten kanssa, jotka ovat eläneet nykyisistä poikkeavissa olosuhteissa.

Historiantutkijat ovat menneen esitysten rakentamisen ammattilaisia ja heidän tuotteitaan pidetään malleina siitä, miten menneen merkityksellisyyttä tulisi lähestyä. Tätä omaan työhön sisältyvää konsultoinnin ulottuvuutta ei ammattikunnan piirissä juurikaan ole pohdittu. Asiaa on lähestytty kovin suppeasti eli tutkijankoulutuksena. Tämän vuoden lopulla Public History Review -aikakauskirjassa ilmestyvä artikkelini käsittelee konsultin tehtävää ihmisten omien historioiden, tai arkikertomusten, rakentamisen kannalta. 
Yksi eteen tulleista ongelmista koski noiden historioiden arviointia, ja sen lähtökohtana oli niiden väistämätön luonne valinnan tuotteina. Koska menneitä asioita tarkastellaan aina jostain tietystä näkökulmasta, voidaan väittāä, että kaikki esitykset ovat yhtä perusteltuja. ”Anything goes" -ajatusta ei silti voida hyväksyä. Historian perustana olevasta dialogista ei voida puhua, jos toinen osapuoli ei saa ääntään kuuluville.

Historiantutkijoiden perinteinen vaatimus menneiden ihmisten toiminnan esittämisestä heidän "omilla ehdoillaan" on perusteltu. On osoitettava, miten väittelyn toinen osapuoli ymmärsi todellisuutensa; on tavoitettava heidän ajattelutapansa ja selvitettävä, millaisen tiedon varassa he toimivat. Historiakonsultin haaste on välittää tämän vaatimuksen mieli ei-ammattilaisille - samalla, kun hän jättää näiden historioiden muodon asianomaisten itsensä päätettäväksi.

Konsultoinnista akateemisen maailman ulkopuolella on itse asiassa tullut kahden viime vuosikymmenen aikana historia-ammattilaisen velvollisuus, sillä ihmiset rakentavat historioita potensseissa enemmän kuin koskaan aiemmin. Perusteluksi riittää viittaus näiden esitysten yksinkertaisimpaan muotoon eli internetiä hyödyntäen huokeasti tuotettuihin valokuvakirjoihin, joissa on vaikkapa vain siteeksi tekstiä. Näillä historioilla on silti myös poliittinen ulottuvuutensa.

\section{Kertomukset ja demokratia}

Yhteiset historiat (shared histories) ovat mennyttä koskevia esityksiä, joita erilaiset yhteisöt (perheet, työporukat, naapurustot, ammattiryhmät, kansakunnat jne.) ovat yhteisesti rakentaneet selviytyäkseen yhteiskunnallisessa ja kulttuurisessa ympäristössään. Nämä kollektiivisen, mutta vain harvoin tietoisen rakennustyön tuotteet, joihin viitataan vain sattumanvaraisesti, ovat mukana kaikissa (so. myös ammattilaisten tuottamissa) historioissa.

Kertomusten esittäminen on tapa, jolla yhteisön jäsenet välittävät toisilleen yhteistä historiaansa, ja juuri tämä tekee kertomukset tärkeiksi demokratian kannalta. Maailmassa, joka on tulvillaan valmiiksi muokattua tietoa ja jossa politiikkaa perustelevat historiat esitetään itsestäänselvinä totuuksina, yhteiset historiat ovat vaille huomiota jätetty vastarinnan voimavara. Nostamalla ne keskustelun kohteiksi konsensuksen välttämättömyydellä lannistetut kansalaiset saavat tilaisuuden tuoda esiin omat kokemuksensa ja niiden perustelemat näkemyksensä.

Yhteiset historiat tiivistävät yhteisön jäsenten kokemuksia ja ovat sellaisina kritiikkiä, jonka kohteena ovat julkista valtaa käyttävien näkemykset kansalaisten tilanteesta. Yhteisistä historioista käyty keskustelu tulisi ajatella demokratian kaikkein keskeisimmän periaatteen toteuttamiseksi: kansalaiset arvioivat omista lähtökohdistaan julkisen vallan käyttäjien toimintaa ja suunnittelevat siihen vaikuttamisen tapoja. 


\section{Lähteet}

ahonen, sirkKa 2012: Coming to Terms with a Dark Past. How Post-Conflict Societies Deal with History. Frankfurt am Main et al.: Peter Lang.

ANDERSOn, Benedict 1983: Imagined Communities. Reflections on the Origin and Spread of Nationalism. London \& New York: Verso.

HYVÄRINEN, MATTI 20I2: Kertomuksen sosiaaliset lajit. Genreanalyysi - tekstilajitutkimuksen käsikirja.Toim. Vesa Heikkinen, Eero Voutilainen, Petri Lauerma, Ulla Tiililä \& Mikko Lounela. Helsinki: Gaudeamus.

JALAVA, MARJA, TIINA KINNUNEN \& IRMA SUlKUnen (TOIM.) 20I3: Kirjoitettu kansakunta. Sukupuoli, uskonto ja kansallinen historia 1900-luvun alkupuolen suomalaisessa tietokirjallisuudessa. Helsinki: SKS.

KALELA, JORMA 2009: Miksi ei pidä ajatella, että historiantutkija tuottaa kertomuksia? Näkökulmia kertomuksen tutkimukseen. Toim. Samuli Hägg, Markku Lehtimäki \& Liisa Steinby. Helsinki: SKS.

KAlela, JORMA 2OI 2: Making History. The Historian and Uses of the Past. Basingstoke: Palgrave Macmillan.

kalela, Jorma (tulossa): The Historian as a Consultant on History-Making. Public History Review 20.

LEHTIPURO, OUTI I982: Historialliset tarinat. Kertomusperinne. Kirjoituksia proosaperinteen lajeista ja tutkimuksesta. Toim. Irma-Riitta Järvinen \& Seppo Knuuttila. Helsinki: SKS.

RosenzWeig, ROY \& DAVId THELEn i 988: The Presence of the Past: Popular Uses of History in American Life. New York: Columbia University Press.

Samuel, Raphael i 994: Theatres of Memory. Vol. 1: Past and Present in Contemporary Culture. London, New York: Verso.

valenius, JOHanna I998: Kertomuksia Suomesta. Historiankirjoitusta sanan voimalla ja kuvan keinoin. Turku: Turun yliopiston Poliittisen historian tutkimuksia 11. 